\title{
Tax Competition and Global Background Justice*
}

\author{
PETER DIETSCH \\ Philosophy, Université de Montréal
}

and

\section{THOMAS RIXEN}

Political Science, Social Science Research Center Berlin

A globalized economy raises intricate questions of distributive justice. Some of these have come under scrutiny in the literature. Under what conditions can international trade be regarded as respecting norms of fairness? Are wages at the subsistence level a necessary step on the path to growth or a form of exploitation? Who does and who should benefit from the profits generated by the exploitation of natural resources? Yet, one important determinant of global justice, namely questions of international taxation, has received little attention in the philosophical debate. ${ }^{1}$ While the importance of taxation as a means of implementing domestic public policy and conceptions of justice is widely acknowledged — and indeed often taken for granted-issues of international tax justice are mostly neglected. Tax competition between states puts pressure on domestic fiscal regimes. Mobile factors of production have the opportunity to "shop around” to minimize their tax burden. This interdependence of national tax regimes generates external effects that undermine the de facto sovereignty of states. As a consequence, tax competition tends to exacerbate inequalities of income and wealth both within countries and across borders. 
One way to address these issues is to condemn the distributive outcomes and to propose redistributive policies to correct what are perceived to be unjust inequalities. This approach is largely remedial. A second possibility is to examine the rules of the game of international taxation themselves, and to make sure they do not contain any unjust bias. This approach, which is geared towards the prevention of injustice in the first place, is the approach favored here. To what extent does the fiscal interdependence between countries call for a normative interdependence in the form of obligations towards other countries that governments have to respect in designing their fiscal policy? How can we delineate legitimate fiscal interdependence from illegitimate tax competition? These are the questions addressed in this article. They target the conditions of global background justice that need to be met to guarantee rules of international taxation that are free from unjust bias. ${ }^{2}$ The reference point for a just international order is one where states have effective sovereignty over their fiscal affairs. Self-determination of this kind serves as the normative premise of our argument. It provides the foundation for advocating functionally differentiated supranational institutions but, importantly, delineates our approach from calls for a wholesale transfer of fiscal sovereignty to a supranational or even world government.

The article is structured as follows. In a first step, we sketch the impact of three different kinds of tax competition—-for portfolio capital, so-called paper profits, and foreign direct investment (FDI) — on the de facto sovereignty of states. We show how tax competition exacerbates social inequalities in order to explain why it is a case of background injustice and should thus be on the radar of theories of justice (Section I).

The central part of the article then lays out two principles of international taxation designed to both protect and circumscribe the fiscal prerogatives of the state. First, a membership principle which holds that deriving the benefits of membership in any given country grounds an obligation to pay one’s taxes there. This principle substantially curtails competition for 
portfolio investment and paper profits. Second, a constraint on fiscal policy that rules out fiscal arrangements which can be shown both to be based on strategic intent—luring in foreign capital—and to have a collectively negative outcome-reducing the aggregate extent of fiscal self-determination. This constraint serves as a tool to assess the legitimacy of fiscal measures to attract FDI. Taken together, the membership principle and the fiscal policy constraint allow us, we argue, to delineate legitimate fiscal interdependence from illegitimate tax competition (Section II).

In Section III, we address the question of how these principles could be implemented. We propose the establishment of an International Tax Organization (ITO) after the model of the World Trade Organization (WTO) and endorse unitary taxation with formulary apportionment (UT+FA) as a reform of corporate taxation. We also evaluate the political feasibility of our proposal.

In Section IV, we discuss the objection that our principles are incompatible with defending a cosmopolitan theory of global justice. Furthermore, we elaborate on the normative status of our account as one of international background justice. Section V concludes.

\section{How Tax Competition Undermines Fiscal Self-Determination}

In this section we show that tax competition leads to policy changes that are not legitimately chosen by the states involved, but forced upon them by competitive pressures. ${ }^{3}$ In other words, tax competition undermines the self-determination of states. We first explain what fiscal self-determination entails and then how tax competition undermines it. 


\section{A. The Content of Fiscal Self-Determination}

In order to establish the fiscal prerogatives of the state, it is useful to step back and consider what the purpose of taxation is. At the most basic level, it is needed in order to finance public goods. ${ }^{4}$ Due to collective action problems their provision generally requires a central enforcement institution, the state. Therefore the prior public good paid for by taxes is the state itself. The state can be viewed as a complex exchange between individuals, performed in order to supply themselves with the public goods necessary to pursue their individual life plans. Under a pluralism of conceptions of the good life, the legitimacy of the state is generally grounded in a democratic form of government, where those subject to the coercively enforced rules of the state are also the authors of these rules.

Importantly, for the purposes of the present section, we take it for granted that polities should be granted considerable autonomy in designing their state institutions. In the fiscal context, a stylized definition of collective self-determination entails two basic choices. These choices respectively concern the size of the public budget (level of revenues and expenditures) and the question of relative benefits and burdens (extent of redistribution). Importantly, these choices of policy objectives extend to the means selected to realize them, like for instance the calibration of the tax mix between direct and indirect taxes. While there are certainly many different views on how these two evidently interdependent choices ought to be made, there is widespread agreement that they constitute the fiscal prerogatives of the state. ${ }^{5}$ This is the substantive content of fiscal self-determination or tax sovereignty. ${ }^{6}$

Three points are worth mentioning. First, we make the simplifying assumption that governments perfectly track their citizens' preferences. ${ }^{7}$ We acknowledge that this is an unrealistic assumption, since government actions often are the result of rather messy and contentious political processes, in which different groups of citizens pursue different interests. 
It is, in reality, not necessarily true that differences in political preferences within the polity of a state are less important than differences between polities. Second, a distinction needs to be made between de jure and de facto tax sovereignty. As will become clear in the next subsection, effective self-determination in fiscal matters requires the latter. Third, selfdetermination is not to be understood in absolute terms. Instead, effective protection from illegitimate interference by other states requires limits on self-determination. Spelling out these limits lies at the heart of this article.

\section{B. The Consequences of Tax Competition}

Tax competition is defined as the interactive tax setting by independent governments in a noncooperative, strategic way. For tax competition to exist there must be fiscal interdependence. This condition is met if tax bases are sensitive to international tax differentials. Tax base mobility must be legally possible and it must actually occur. ${ }^{8}$ Favorable tax conditions to attract foreign capital can be brought about in various ways, such as a reduction in tax burdens (be it by reducing tax rates or defining tax bases in favorable ways), fashioning preferential tax regimes for foreigners, or creating (or not closing) tax loopholes, for example through implementing bank secrecy rules or a lax enforcement of existing rules.

Tax competition primarily targets capital, which is mobile internationally. ${ }^{9}$ Governments use different strategies and tax instruments depending on the kind of capital targeted. Three kinds of capital can be distinguished. First, in the area of portfolio capital of individuals and firms, so-called “tax havens” often have low or zero tax rates. More importantly, they offer strict bank secrecy rules as well as certain legal constructs such as trusts that enable individuals to hide their ownership vis-à-vis tax administrations in their state of residence. 
The taxpayer's behavior in these cases constitutes illegal tax evasion. Due to its illegality it is hard to come up with reliable figures, yet the available evidence suggests that these policies have a real impact. Estimates of the worldwide yearly revenue losses to government coffers range from USD155-255 billion. ${ }^{10}$

Second, governments compete for so-called paper profits. Through various techniques, such as manipulating transfer prices (especially of intangible assets) and thin capitalization, multinational enterprises (MNEs) can assign profits made in high-tax countries to their subsidiaries in low-tax countries without relocating real business activity. Such "tax planning” activity of MNEs is not necessarily illegal; it constitutes (legal) tax avoidance. ${ }^{11}$ Despite different approaches, all empirical investigations into this issue come to the same conclusion: the transfer of taxable profits is very sensitive to taxation, and companies make ample use of these possibilities. The decisive factor in attracting mobile profits is the nominal tax rate, because companies shift only those profits that cannot be offset against depreciation and other tax benefits. ${ }^{12}$ Again, governments may also decide to compete via specially designed regimes to attract paper profits. For example, the regime of Special Financial Institutions (SFI) in the Netherlands allows foreign companies to channel capital through them in order to realize tax benefits.

Third, there is competition for FDI in the form of real business activity, for example the location decisions of MNEs. These business decisions depend on various factors such as countries' respective levels of education, costs of labor, and quality of infrastructure. But the effective tax burden also plays a role. Empirical studies come to the conclusion that raising taxes decreases the inflow of FDI. However, the direction and strength of the correlation is strongly affected by the method of measurement and the kinds of tax rates investigated. ${ }^{13}$ In their quest to attract FDI, governments may either lower the general business tax rate or 
engage in designing so-called preferential tax regimes, which grant tax advantages to foreigners only (ring fencing).

Standard economic theory predicts a "race to the bottom" in capital taxation and the underprovision of public goods in all jurisdictions. ${ }^{14}$ While this extreme outcome cannot be observed empirically, it can be shown that tax competition undermines the fiscal selfdetermination of states, that is, their ability to effectively set the size of the budget and the extent of redistribution. In OECD countries, nominal corporate tax rates have fallen from an average of 50\% in 1975 to an average of $25.7 \%$ in 2010 . Over the same period, nominal top personal income tax rates have fallen from $70 \%$ to $41.4 \%$. These rate cuts were refinanced by broadening the bases on which taxes are applied ("tax cut cum base broadening”). As a result, corporate tax revenue as a percentage of GDP remained stable at an average of about $2.5 \%$, whereas income tax revenue even rose from $11.2 \%$ to $12.8 \%$ of GDP. ${ }^{15}$ The trend towards low nominal tax rates and broad tax bases is an attempt to defend against the outflow of mobile profits and at the same time prevent an adverse revenue effect. ${ }^{16}$

While revenue losses did not occur, the "tax cut cum base broadening” policy affects the distribution of the tax burden among different kinds of taxpayers. For one, there is an effect within the business sector: highly profitable MNEs benefit, while nationally organized small and medium-sized enterprises are more heavily burdened. Second, the tax burden is shifted from capital to labor. This is also visible in the general trend to increase indirect taxes, such as consumption taxes. Last but not least, competitive downward pressure on corporate tax rates affects the distributional characteristics of the personal income tax. If the nominal corporation tax rate is lowered, then it is worthwhile for private individuals to re-label their income by incorporating. In order to prevent such arbitrage, policy makers often align the corporate tax rate and the top rate on personal income, thus flattening the personal income tax schedule. ${ }^{17}$ 
As for developing countries, the dynamics of a race-to-the-bottom have a more visible impact. The pressure from tax competition on public finances is comparable to OECD countries, but developing countries usually do not have the administrative resources to stabilize their revenues by broadening tax bases. On the contrary, in many countries the base has been narrowed. ${ }^{18}$ A significant part of the revenue loss is directly due to the shifting of paper profits. One study estimates the annual revenue loss of developing countries from transfer pricing to be USD 160 billion. ${ }^{19}$

Overall, the empirical evidence shows that tax competition undermines fiscal selfdetermination. ${ }^{20}$ While states still possess the formal right to set tax policies (de jure sovereignty), they cannot effectively pursue their desired policy goals (de facto sovereignty). Developed countries are able to maintain the size of the budget (the first component of selfdetermination), but this can only be achieved by compromising the desired extent of redistribution (the second component of self-determination). By contrast, developing countries are not able to prevent revenue losses and thus lose out on both components of fiscal self-determination. In this respect, tax competition increases existing inequalities between countries of the global North and South. For these reasons, we consider international tax competition in its present form to be a case of background injustice. In the absence of an institutional framework to regulate it, it introduces multiple kinds of bias into the international fiscal regime that lack justification.

\section{Two Principles of Global Background Tax Justice: Membership and Fiscal Policy}

\section{Constraint}


The last section specified the content of fiscal self-determination and demonstrated how it is endangered by tax competition. Just like in the case of individual liberty, to be effective the liberty to make these collective choices is restricted by the same liberty for the citizens of other countries. The two principles we will advance in this section spell out these restrictions and are meant to ensure that countries have an effective right to tax that reflects their polities' choices about the size of the state budget and the desired extent of redistribution. The membership principle is based on the intuition that capital mobility renders this liberty fragile and that it therefore needs to be protected. The fiscal policy constraint argues that this liberty can be abused and therefore calls for it to be circumscribed.

\section{A. The First Principle: Membership}

Imagine you live on a street with two health clubs. One high-end club with expensive equipment and all kinds of freebies like club towels and shaving equipment, and one less fancy club that lacks the rowing machines, has only three step masters instead of ten and no

freebies. Unsurprisingly, the membership fee of the high-end club is almost three times that of its no-frills competitor. You are a member of the no-frills club. One day, you discover that your membership card actually lets you pass the turnstile at the high-end club, too. You keep quiet and start working out there. As it turns out, quite a few members of the no-frills club frequent the fancy club. A month later, you bump into a friend in the washrooms of the highend club. "What are you doing here?” he asks. With a sheepish look on your face, you tell him about your discovery. He is enraged. "You guys are free-riding on our membership fees.” He informs the manager and, the next day, the high-end club starts issuing new membership cards. This reaction appears justified. 
For the purposes of our argument, the analogy between countries and health clubs is a useful one. There are places, such as the Scandinavian countries, that provide more services like state-financed daycare, more generous unemployment insurance, and so on, but in turn also "charge" more in terms of taxes. ${ }^{21}$ There are others, like England, where citizens prefer to have a leaner set of services and hence pay less. Certain forms of tax planning that involve shifting one's tax base to a low-tax jurisdiction without moving the underlying activity itself are parallel to using the high-end health club on your no-frills card. When a company uses the services of a country — that is, its infrastructure, human capital, and so on — to produce a certain commodity, but then shifts the paper profit made with this economic activity to lowtax jurisdictions through practices like transfer pricing or thin capitalization, the citizens who finance these services have a legitimate complaint. Tax evasion on portfolio capital, as suggested by its illegality, represents an even blunter form of abuse and can be likened to jumping the turnstile at the high-end health club when no one is watching.

We are now in a position to formulate our first principle of international taxation, the membership principle:

Natural and legal persons should be liable to pay tax in the state of which they are a member.

In order to apply the principle, it is necessary to define membership. Our definition is the following: individuals and companies should be viewed as members in those countries where they benefit from the public services and infrastructure. ${ }^{22}$ This conception of membership is related to, but distinct from, what is called the "benefit principle” or the principle of "fiscal equivalence" in the public finance literature. ${ }^{23}$ The benefit principle is usually contrasted with the ability to pay principle. ${ }^{24}$ Whereas the latter justifies redistribution, the former does not and makes taxes strictly proportional to the individual benefits taxpayers receive in return. Our conception of membership is more general and comprises both of these principles. It is 
compatible with what has been called "group fiscal equivalence," ${ }^{25}$ which demands that the collective benefits of the group of citizens should be proportional to the amount of taxes paid. It thus allows for redistribution among individuals and corporations. As implicit in our notion of fiscal self-determination, the citizens of a state may (or may not) decide that it is appropriate to tax higher incomes at higher rates. ${ }^{26}$ On this issue, the above analogy between the health clubs and countries breaks down. True to its objective to re-establish the de facto sovereignty of states, the membership principle is silent on the actual tax system chosen by polities. It merely stipulates that polities should have an effective right to tax individuals and companies as they see fit.

The remainder of this section is dedicated to two sets of comments on the membership principle. The first concerns its relation to existing principles, rules, and practices of international taxation. The second set of comments gauges the potential impact of respecting the membership principle on international taxation.

Our definition of membership is broad enough to encompass the major intuitions of diverse theories of international taxation. In the international tax literature, there is agreement that a nexus of some sort between taxpayer and country is required to justify taxation. Yet, there is disagreement about the proper nature of this nexus—should it be economic, social, political, or territorial allegiance, or a combination of these? The disagreement has never been fully resolved at the level of principles. ${ }^{27}$ This is unsurprising, given that each pure solution has distributive consequences that favor the material revenue interests of certain groups of countries over others. ${ }^{28}$

Nevertheless, a working compromise has been found. According to the so-called “international tax principles” individuals are assessed on a residence basis, because residence determines where they benefit from public services and where they should therefore be counted as a member. Companies benefit from public services and infrastructure in the 
country where their substantive activities take place. Beyond a certain threshold of economic activity, they are therefore liable to tax in source countries, that is, those countries where the income was generated. For MNEs whose activities spread across borders, membership comes in degrees and should correspond to the distribution of its economic activities among countries. This justification for a combination of the residence and source principles of international taxation is commonly accepted. While the detailed definition of membership for particular cases remains a thorny and often controversial issue that keeps many tax experts busy, the distribution of taxing rights broadly follows this pattern, which is in line with our membership principle.

However, there are two practical problems. First, even though their underlying rationale is in line with our membership principle, the actual international tax rules, which are made up of domestic tax laws, bilateral double tax agreements (DTAs), and non-binding model conventions of international organizations, create certain overlaps (so-called double taxation) and gaps (double non-taxation) in countries’ taxing rights. ${ }^{29}$ As described in Section I, these grey zones can be exploited by sophisticated taxpayers to minimize their tax bill, thus violating the membership principle. Second, tax arbitrage aside, the current rules are badly enforced. There is no international authority overseeing state compliance, and administrative assistance and information exchange between countries is underdeveloped. Hence, it becomes possible to pass under the radar of tax authorities, thus violating the membership principle.

This brings us to our second set of comments. How would respecting the membership principle change the international tax landscape? While the detailed answer depends on the way it is institutionalized, a general observation can be made. The membership principle ensures that tax competition is brought closer to Tiebout's idealized notion of "voting with your feet.” 30 Tiebout's model is generally presented as a justification for tax competition. It is argued that competition among jurisdictions leads to an efficient allocation of public funds as 
individuals self-select into different jurisdictions according to the match between the various tax-expenditure packages on offer and their fiscal preferences. ${ }^{31}$ A crucial assumption of the model is that there are neither positive nor negative externalities for other countries stemming from the provision of "local” public goods. Yet, this assumption will generally not hold. When public goods are modeled more realistically as generating externalities, they will be underprovided if left to the market. Under these conditions, H.W. Sinn has shown that tax competition is nothing other than the introduction of the market mechanism "through the backdoor” and fails to produce an efficient allocation of public funds. ${ }^{32}$

While the costs and benefits of government action will never align perfectly in an economically interdependent world, the membership principle works to minimize the gap between them. It prohibits the hiding or shifting of part of the tax base from one's residence state in the case of individuals and from the source state in the case of MNEs. If it were implemented, two of the three kinds of tax competition, namely targeting portfolio capital and paper profits, would be curtailed and free-riding would no longer be possible. Any relocation of residence in the case of individuals and of real investment in the case of companies, however, would be unproblematic, since in those cases taxes are paid where the benefits from public services and infrastructure are obtained. A shift from the status quo to a world where the membership principle is respected would be a shift from a world of (merely) virtual tax competition for portfolio capital and paper profits to a world of real tax competition for FDI.

Note, however, that the membership principle not only sanctions the relocation of real investment but, by making virtual tax competition impossible, it is likely to make the competition for 'real' FDI more intense. If taxpayers cannot realize tax advantages by shifting portfolio capital or paper profits anymore, the incentive for actual relocation increases. ${ }^{33}$ If this is so, it becomes all the more important to determine whether real tax competition is in line with fiscal self-determination and, if so, to what extent. 


\section{B. The Second Principle: A Constraint on the Design of Fiscal Policy}

There is a basic difference between the three kinds of tax competition laid out in Section I. Whereas in the case of competition for portfolio capital and paper profits, countries aim to attract the tax base of people who remain members of another jurisdiction, competition for FDI implies a change of membership for the individuals or corporations who follow their capital to the new jurisdiction. The former phenomenon has been called "poaching" by the OECD ${ }^{34}$ reflecting intrusion or free-riding on someone else's fiscal territory; the latter phenomenon could be labeled “luring.” In this section, we argue that some, though not all, cases of luring are problematic from a normative perspective and that, hence, fiscal selfdetermination needs to be curtailed in certain ways.

A limitation of sorts to fiscal self-determination should not come as a surprise. After all, it is a constitutive feature of any right that, in order to be effective across its various holders, it will have to be limited. Against this background, while the membership principle is designed to protect fiscal self-determination, the constraint on fiscal policy to be developed in the present section circumscribes it.

To motivate the normative relevance of cases of luring, consider the case of Ireland. For decades, Ireland had a tax rate between $10 \%$ and $12.5 \%$ on corporate profits, which drew in up to $25 \%$ of the FDI American corporations made in Europe. ${ }^{35}$ This arrangement was a major factor behind the- - by European standards_-phenomenal growth of the Irish economy in the decades immediately preceding the 2008 financial crisis, and is therefore regarded by many economic commentators as a useful and effective tool of public policy. Any argument that claims luring to be problematic from a normative perspective will have to engage with 
this classic case for tax competition invoked by those countries that successfully employ it to promote economic growth.

So, what is wrong with luring from a normative perspective? We will discuss two tentative replies to this question and argue that while both are unsatisfactory when considered on their own, taken together they can both delineate the problematic aspects of luring and help formulate an adequate regulatory response. In a nutshell, one might object to luring either because it produces bad outcomes or because the intentions behind it are objectionable. We will start with the former.

a) An outcome-based constraint. As has been demonstrated in Section I, tax competition undermines the fiscal prerogatives of the state. It puts pressure on a government's capacity to realize their citizens' preferences concerning the size of the state as well as the level of redistribution. This is so even if the membership principle were fully implemented, because as argued above tax competition will generally not function as perfect Tiebout competition since it does generate fiscal externalities across jurisdictions.

These considerations prepare the ground for an outcome-based principle as one candidate for a constraint on fiscal policy:

A tax policy is legitimate if it does not produce a collectively suboptimal outcome. A collectively suboptimal outcome is here defined as one where the aggregate extent of fiscal self-determination of states is reduced.

Such a principle would not only rule out all effective tax competition, i.e. tax competition that actually succeeds in luring FDI, but it would impose far more drastic limits on fiscal policy. Suppose that, in a two-country world, the English have a preference for a leaner state and lower level of redistribution than Swedes. Suppose also that, to realize these preferences, the English lower their corporate tax rate. This leads to an inflow of Swedish FDI to England. In that scenario, the English continue to live out their fiscal preferences to the same extent as 
before, whereas the Swedish face a new constraint on their fiscal sovereignty. In the aggregate, the extent of fiscal self-determination of all countries is reduced. Even though England is not purposefully luring in Swedish capital, this is the outcome of its policy, and the above principle would therefore have to consider it illegitimate. The candidate principle would undermine precisely the kind of fiscal sovereignty that the membership principle is designed to protect and, in this sense, overshoot its target. It would fail to delineate mere fiscal interdependence from illegitimate tax competition.

b) An intention-based constraint. Rather than trying to delineate legitimate fiscal interdependence from illegitimate tax competition by appeal to outcomes, an alternative strategy is to focus on the intention that motivates the tax policy in question. Is it not the fact that Ireland deliberately tries to lure in foreign corporations and their capital that raises hackles and poses problems from a normative viewpoint? Could an argument be made that this is objectionable?

Such an argument can appeal to the intuition that fiscal prerogative trumps strategic intent. Consider the following two cases. First, the England-Sweden case discussed above. The tension between the fiscal prerogatives of the two countries here is constitutive of a fiscally interdependent world without tax harmonization. Privileging the fiscal prerogatives of Sweden over those of England seems unwarranted and overshoots the target. Second, think again of the Irish case. Here, the tension does not occur between two sets of fiscal prerogatives, but between the strategic intent of Ireland and the fiscal prerogatives of other countries. After all, the practice of luring in more members does not form one of the fiscal prerogatives of the state. The fiscal prerogatives of other countries trump the strategic intent of the Irish in this case.

It is worth highlighting that, at least in one respect, an intention-based constraint is an improvement on the outcome-based constraint discussed above. While the latter was not able 
to drive a wedge between mere fiscal interdependence and tax competition, the criterion of strategic intentions does exactly that. This is a considerable advantage.

However, an appeal to intentions suffers from an important drawback of its own. If one condemns instances of strategic luring of foreign capital, does this condemnation not have to extend beyond tax competition narrowly defined? If strategic intent is the normative hitch, what should one make of investments in infrastructure or in human capital? Ruling out strategic intent across the board would not only deprive governments of substantive policy tools, but it might also have negative consequences in some contexts. Take the example of strategic infrastructure investments. Suppose Belgium invests in high-quality and specialized infrastructure in order to attract entrepreneurs from various countries, who profit from the fact that many people and firms from the same sector are geographically close. Over time a highly interdependent cluster develops. These agglomeration effects will positively impact growth in the country. ${ }^{36}$ As a reaction, other countries may follow suit in promoting infrastructure or technology clusters. The result is a race to the top. While it is true that the initial move by Belgium temporarily violates the fiscal prerogatives of other countries, the resulting economic growth and tax revenues will allow the other countries to realize their preferences in terms of fiscal prerogatives in the long run. ${ }^{37}$ In these cases, there is no need to rule out strategic considerations.

Like an outcome-based constraint, an intention-based constraint overshoots the target, albeit in a different way. It cannot distinguish regulatory competition with good versus bad collective outcomes. We submit that the difficulties of these approaches taken in isolation can be overcome by combining them into a mixed constraint.

c) A mixed constraint. An adequate constraint on the design of national fiscal policies is one that weighs the necessary protection of fiscal sovereignty against the costs it imposes on other countries. ${ }^{38}$ We believe that such a constraint should be sensitive both to the intention 
behind the fiscal policy in question and to the consequences on aggregate de facto fiscal sovereignty. What would such a mixed constraint look like?

Consider the intentions component first. While the basic practical question of how to assign intentions to a state in the first place will be discussed in Section III, we are here concerned with the criterion that decides whether an intention is strategic or not. We propose the following test. Suppose the benefits of a tax policy change in terms of attracting tax base from abroad did not exist. Would the country still pursue the policy under this hypothetical scenario? If yes, the policy is evidently not motivated by strategic considerations and therefore is legitimate. If not, it is strategically motivated, but the verdict depends on the impact of the policy on the aggregate fiscal self-determination of all countries.

"Strategic" here implies that a policy is justified by the prospect of luring in mobile capital from abroad rather than by appeal to the fiscal prerogatives of the state defined in Section I. The counterfactual nature of the criterion allows us, on a conceptual level, to elicit the motivation of a country in pursuing any given fiscal policy. ${ }^{39}$ Note that it also captures cases of mixed motives, where a country lowers a certain tax rate in part because this reflects the conception of justice of its citizens, but also because of the strategic value of doing so for attracting foreign tax base.

Second, the causal impact of a specific fiscal policy on the fiscal prerogatives of all affected states will have to be evaluated. The criterion for assessing this impact is the one already discussed above: a tax policy is legitimate if it does not produce a collectively suboptimal outcome, that is, a negative impact on the aggregate extent of fiscal selfdetermination. While unsatisfactory on its own, it combines with the test for strategic intention to provide a good yardstick to evaluate fiscal policies. If this assessment were to be tackled entirely as a projection into the future, it would be too speculative in nature to be reliable. Yet, as we set out in detail in Section III, we propose an arbitration procedure under 
which countries bring forward cases that their fiscal prerogatives have been violated by the fiscal policy of others. The at least in part backward-looking character of this procedure renders the task of evaluating outcomes feasible.

Even though we acknowledge that both assessing intentions and evaluating outcomes remain daunting prospects, we believe they are feasible. As Section III will argue, there are precedents in the practice of international law that justify this optimism.

To sum up the conceptual implications of our proposed mixed constraint as well as its advantages over the two candidate constraints discussed before, consider Table 1 .

\begin{tabular}{|l|l|l|l|}
\cline { 3 - 4 } \multicolumn{2}{c|}{} & Outcome \\
\cline { 3 - 4 } \multicolumn{2}{c|}{} & Good & Bad \\
\hline \multirow{4}{*}{ Intent } & Independent & 1 & 2 \\
& & $\checkmark$ & $\checkmark$ \\
\cline { 2 - 4 } & Strategic & 3 & 4 \\
& & $\checkmark$ & 区 \\
\hline
\end{tabular}

Table 1: A mixed constraint on fiscal policy

Fiscal policies that are formulated independently of their impact on international capital flows and have a positive outcome (quadrant 1 of the matrix) are clearly unproblematic. A domestically motivated decision to invest in infrastructure which then has positive knock-on effects on the infrastructure abroad ("race-to-the-top”) could be an example.

Fiscal policies that are formulated independently but have a negative outcome (quadrant 2) are problematic, but ruling them out would impose too powerful a constraint on the design of fiscal policy (as demonstrated by the England - Sweden case).${ }^{40}$ Doing so is the weakness of a purely outcome-based constraint as discussed above. 
Fiscal policies that are formulated strategically but have a positive outcome (quadrant 3) may at first appear to violate fiscal sovereignty, but a closer look reveals they do not because they lead to a race to the top (as demonstrated by the Belgium example). A drawback of a purely intention-based constraint is that it would rule out strategically motivated policies irrespective of their effects.

Finally, policies that are formulated strategically and have a negative outcome (quadrant 4) are problematic on both counts and should therefore be prohibited. This is what our mixed constraint is designed to do. The Irish case falls into this category.

Before moving on to questions of implementation, we need to discuss one potential objection to our partial appeal to intentions in evaluating fiscal policy. Suppose the citizens of a developing country are motivated by social justice reasons to build more hospitals and, in order to do so, decide to lower their country’s taxes to attract the necessary capital from abroad. Is this part of their fiscal self-determination or should it count as a strategic consideration? Would we not deprive poor countries of an important source of redistribution if it turned out that such a strategic policy contributes to a race-to-the-bottom? We believe that our principle can answer these questions.

First, we submit that this policy should indeed count as motivated by strategic considerations. Capital that is attracted to the developing country to build a hospital is not available to build a hospital elsewhere. Second, this does not mean that building the hospital in the developing country is not important and does not preclude the possibility that richer countries have an obligation of assistance towards this project. But this obligation should not be discharged in the form of a bias in the way the jurisdictional structure of international taxation is set up. It should rather be dealt with via explicit redistribution. ${ }^{41}$ This illustrates that a complete account of tax justice has two components - the fair rules of the game that lie at the heart of this article and redistributive obligations, which we bracket here. Attempting to 
assess redistributive obligations before the fair rules of the game have been determined amounts to a Sisyphean task. Redistribution to correct for an institutional bias and injustice is analogous to swimming against the current—it takes a lot more energy while getting you less far.

In fact, this issue is not simply hypothetical. There is a debate about the legitimacy of developing country tax havens. When OECD countries began to pressure tax havens to abandon their harmful tax policies (see below), some of them argued that they had chosen to become tax havens because they saw no other possibility to initiate economic development. ${ }^{42}$ Rich countries may well have an obligation to compensate these states.

\section{Institutionalizing the Two Principles}

It is notoriously difficult to derive concrete institutions from abstract principles, because there will generally be more than one way to institutionalize a principle. In the face of this institutional indeterminacy, we limit ourselves here to demonstrating that there is an institutional solution that satisfies the conditions embodied in our principles. As a further caveat, we stress that the following sketch cannot, due to space constraints, do full justice to the complex issues of international tax law. But it should suffice to outline some possible institutional implications of our proposal.

Any institutional solution must: (1) provide a forum for governments to negotiate agreements on the rules of international taxation; and (2) make sure that the rules are enforced. In the following we propose the establishment of an International Tax Organization (ITO) and discuss the basic institutional design features required to ensure it is up to the two 
tasks. ${ }^{43}$ The ITO should become the forum for negotiating and defining the rules in line with the membership principle and the fiscal policy constraint. To ensure a level playing field, all states should be members and adequately represented in the ITO’s decision-making procedures, which, in a world of power politics, does of course represent a challenge in its own right. ${ }^{44}$

\section{A. Institutionalizing the Membership Principle}

On the basis of our two principles several reforms become imperative. First, governments have to abolish all rules that make it impossible for other countries to enforce the membership principle. Thus, strict bank secrecy regulations, the supply of other deliberately nontransparent legal constructs, and the refusal to exchange information with other tax administrations will be ruled out. The requirement to exchange tax-relevant information with other countries could be implemented through a system of multilateral automatic exchanges of information.

Second, an ITO with inclusive membership would provide an ideal forum to reconsider the membership rule in the case of MNEs. How should the rights to tax shares of the profit of an MNE be allocated among jurisdictions? This issue is a very thorny one in international tax practice that has so far been resolved through so-called separate entity accounting and arm's length standard (ALS) transfer pricing. ${ }^{45}$ As set out in Section I, both the indeterminacy of applying this standard and the difficulties in its enforcement can be exploited by MNEs to lower their tax bills. One possible solution would be to switch to a system of unitary taxation with formula apportionment (UT+FA). ${ }^{46}$ This would require governments to agree on a common and consolidated corporate tax base. MNEs would have to determine their 
worldwide profit in one single report, and they would be allowed to consolidate profits and losses of entities in different countries. The worldwide profit would then be apportioned to the respective countries in which the MNE operates on the basis of a predetermined formula. The formula should reflect the real economic activity in each country by referring to factors such as property, sales, and payroll. This would make it impossible for companies to engage in the shifting of paper profits and would thus be a major step forward in the implementation of the membership principle.

\section{B. Institutionalizing the Fiscal Policy Constraint}

As we have already acknowledged, defining rules that respect the constraints on fiscal policy will be difficult. First, the outcome on which we focus, namely constraints on aggregate fiscal self-determination of countries as a result of national tax policies, may not be easily observed, especially across alternative regulatory regimes. However, in principle it should be possible for a government to make the case, and support it with empirical evidence, that it has lost tax base to another country that has recently changed its tax policies. Second, and more importantly, the fact that intentions are unobservable invites hypocrisy. It will be possible for governments to misrepresent their intentions, that is, to attribute any tax reforms to the preferences citizens have about the size of the budget and the extent of redistribution, even if in reality they pursue the strategic aim of attracting foreign tax base. In order to avoid hypocritical political discourses and long but futile attempts to distinguish honest from dishonest representations of intentions, the institutionalization of the principle should as much as possible rely on objectively observable proxies for the defendant's intentions. To get off 
the hook, the defendant would need to show that the tax policy change in question has actually had beneficial effects collectively.

While a detailed and legally applicable definition of the objective factors that indicate a bad outcome and a strategic intention of the defendant is a task for tax lawyers, and thus beyond the scope of this article, it is clear that data on capital flows, economic growth rates, or distributive results are readily available and could be used by the parties to a tax dispute. Reference to these indicators is routinely made in all kinds of debates on policy design; international fiscal policy is no exception in this respect. Nevertheless, given the many factors that affect economic outcomes and the complex relationships among them, controversies over the right interpretation of these data are likely. In case of controversy, what is needed is an accepted independent third party that can settle the dispute through an authoritative interpretation of the facts. As described in the following section, what we envisage is a judicial or quasi-judicial system in which disputes among governments over tax policy can be settled. Here, it is worth noting that courts assess intentions on a regular basis in the international arena. For example, the International Court of Justice (ICJ) has to assess the intentions of the alleged offender in applying the genocide convention. ${ }^{47}$ The WTO is another case in point. Under the rules on non-tariff trade barriers, policies with protectionist effect are generally prohibited. However, in case a country pursues a policy with the intention of protecting consumers' health and safety and can prove its good intentions, an exception to the rule of non-protectionism is granted. As in our proposal, the WTO institutionalized this rule by focusing on the observable implications of countries' intentions. A government has to provide valid scientific evidence of the claimed adverse effects on consumers' health and safety. $^{48}$

In addition to these considerations, it is possible to derive one necessary, but not sufficient, condition for satisfying the fiscal policy constraint: all forms of preferential tax regimes for 
foreigners (ring fencing) must be abolished. The only plausible explanation for such discriminatory arrangements is strategic intent to lure in foreign capital. As to its consequences, discrimination of this kind will generally not have positive effects in the sense of a race to the top.

\section{Enforcement}

What would it take to effectively enforce our two principles? Monitoring compliance should be relatively straightforward since governments can be expected to launch a complaint if other governments violate either or both of the two principles. Yet, what is needed is an independent authority that will process the complaints and eventually enforce the rules. Effective enforcement is needed to ensure compliance with the two principles, because the structure of tax competition is such that every individual country has an incentive to deviate from the collectively desirable rules. The ITO could install a dispute settlement procedure after the WTO model to satisfy this requirement. ${ }^{49}$ In case a member state complains that the tax practices of another member violate the rules, they can, as a first step, try to resolve the conflict in consultations. If they are unsuccessful, the case will be transferred to the dispute settlement body (DSB), which effectively functions like an independent judiciary, because a panel report (judgment) can only be blocked if all member states unanimously agree on blocking it. Since parties know that there will be effective enforcement of decisions in the DSB, it can be expected that they will resolve many cases in consultation. This procedure has the advantage of avoiding excessive litigation and leaves room for political negotiations and decisions. 
One potential objection to the ITO is that it is another non-majoritarian institution which is provided with substantial enforcement powers but lacks democratic accountability and legitimacy. ${ }^{50}$ This is an important concern. Yet, we believe that the status quo, with its hollowing out of effective fiscal sovereignty through tax competition as described in Section I, is even more problematic in this respect. Although it formally guarantees democratic accountability, de facto this is not the case. Conversely, while an ITO may reduce the scope of fiscal policy issues for which there is direct democratic accountability, it would make sure that the latter can actually work effectively in this restricted realm.

\section{The Contrast with the Status Quo and Feasibility Issues}

How does our proposal for the future rules of international taxation compare with the institutional status quo? Is it feasible in the sense that it relies on solutions that have successfully been put to work in other contexts or policy fields?

As described in Section I, the current situation is characterized by harmful tax competition. This fact has not gone unnoticed by governments and international organizations. Accordingly, they have launched policy initiatives to address this situation. We now very briefly summarize the results of the two most important instances - the efforts of the OECD and the EU. The ongoing OECD initiative against harmful tax competition ${ }^{51}$ has so far hardly brought any tangible progress. It focuses on information exchange on request, which is provided for in bilateral tax treaties. Under the on-request system, the requesting state has to present initial evidence of international tax evasion in order to receive the required information about foreign funds of its residents. Yet, precisely the kind of information required to mount an initial case is often secret and thus on-request information exchange is 
ineffective. Routine, electronic (that is, automatic) and multilateral exchange of information on the funds of non-residents to their respective home countries, as foreseen in our proposal, can address this problem. ${ }^{52}$ Moreover, the OECD can only issue non-binding recommendations and countries are not obliged to implement them. ${ }^{53}$

The EU has been somewhat more successful in its initiatives against harmful tax competition. With respect to business tax competition, the Council agreed on a soft law Code of Conduct in 1997. Member states entered into a non-binding commitment to remove socalled preferential tax regimes. Despite being non-binding, the code developed some bite because compliance with it was made a condition of accession for the Central and Eastern European countries. Also, the Commission applied the principles contained in the code to its state aid rules, which thus increased compliance among the EU-15 states. ${ }^{54}$ Currently, the EU is considering adopting a system of unitary taxation with formula apportionment. ${ }^{55}$

In the area of portfolio tax competition the EU has passed the Savings Tax Directive, which took effect in July 2005. This directive targets tax evasion on interest income by requiring automatic information exchange among countries on the savings of foreign residents. While the directive has significant loopholes, it is important in that it shows that automatic international information exchange can be implemented in practice. ${ }^{56}$

Our proposal significantly improves upon these initiatives. In line with the normative demands of our two principles we propose an international framework that is much stronger than the current global tax institutions, which cannot make universally binding rules and lack international levers of enforcement. Moreover, the OECD, as today's most important international tax forum, is made up only of industrialized countries, a fact that has invited the criticism of imperialism. The proposed ITO with its encompassing membership would remedy this shortcoming. 
The experience at the regional level of the EU shows that creating an institutional framework with more effective powers of enforcement is indeed feasible. The EU uses one of the specific policies we recommend, namely automatic information exchange, and is seriously debating another one, UT+FA. At the same time, note that our proposal, while it does involve a redefinition of fiscal sovereignty, does not require the transfer of core fiscal prerogatives to the international level. No supra-national power to tax is established. Instead, the basic idea is that the international community protects national fiscal self-determination by imposing certain limits on the fiscal choices of nation states. The existence of the WTO is testament to the fact that creating an international organization to define and enforce these constraints is achievable. $^{57}$

An additional argument for the feasibility of our proposal is that it does not envisage harmonization of national tax policies. While harmonization is portrayed as the relevant alternative to tax competition in large parts of the literature, ${ }^{58}$ it is also clear that there are strong political objections against it. We submit that our principles can address the undesirable aspects of tax competition without implying full harmonization. First, respect of the membership principle and the fiscal policy constraint does not entail harmonization. Suppose the English really do have a preference for a smaller state and less redistribution than the Swedish. Neither of our principles will stop them from designing a tax structure that reflects these preferences. In turn, nothing we have said will prevent the Swedes from making a democratic choice that the best way to finance a relatively generous welfare state is to shift a considerable portion of the tax burden onto labor and consumption and to tax capital lightly, as they in fact do. However, the proposed constraint on fiscal policy prohibits the very same policies if they are based on strategic considerations and have negative consequences.

Second, even in a world where different polities have divergent preferences about the size of the state and the extent of redistribution, our two principles will create some pressure 
towards convergence. This is so because countries with preferences for a relatively large state and/or a high extent of redistribution will now have to bear the real costs of these preferences in terms of part of their tax base voting with its feet. At the other end of the spectrum, however, the danger of a race to the bottom would be eliminated by our two principles for the very same reason. Countries with smaller state budgets and a lower level of redistribution would also be forced to bear the full costs of their tax structure, rather than being able to finance part of their public services by strategically attracting foreign tax base. The fiscal externalities generated in both directions under our two principles are those minimally present under conditions of fiscal interdependence between states. ${ }^{59}$ They ensure a maximumthough less than perfect—correspondence between the convictions of members of the respective polities and the fiscal structure of those polities.

\section{Toward What Kind of Global Justice?}

We have pointed out that the membership principle and fiscal policy constraint serve to protect the de facto sovereignty of states and their capacity to implement the conception of justice of their citizens domestically through their fiscal policy. Yet, what about global justice? Arguably, the most disturbing inequalities in today's world are ones between individuals across borders rather than between citizens of the same state.

Our account owes two explanations in this context. First, we need to justify granting states fiscal self-determination in the first place-a question that we bracketed in Section I. Without such a justification, which requires a theory about the fundamental relationship between social justice, democracy, and global justice, our principles could be accused of being constructed on theoretical quicksand. We do not aim here to provide a full-fledged justification of the 
state. Instead, our objective is to survey a number of potential justifications of the state and to argue that the theories of global justice that underpin them — notably cosmopolitan ones—are not at odds with our principles and the fiscal self-determination the latter imply. Second, a clarification concerning the normative status of the two principles is in order. In the second part of this section, we will elaborate on what we have in mind when presenting them as principles of global background justice.

\section{A. The Normative Grounds of Self-Determination}

Consider the following formulation of the basic tenet of cosmopolitanism: "moral cosmopolitanism holds that all persons stand in certain moral relations to one another: we are required to respect one another's status as ultimate units of moral concern—a requirement that imposes limits upon our conduct and, in particular, upon our efforts to construct institutional schemes." ${ }^{60}$ Moral cosmopolitanism is to be distinguished from legal cosmopolitanism, which calls for a global order in which people have "equivalent rights and duties."61 While the latter, more radical version of cosmopolitanism is indeed incompatible with state autonomy, most cosmopolitan theorists endorse the more moderate variant of the cosmopolitan ideal. ${ }^{62}$

It is not our goal here to endorse cosmopolitanism or any other theory of global justice. We merely aim to anticipate and counter the objection that the principles of international taxation developed in Section II and the self-determination of states they advocate conflict with moral cosmopolitanism as defined above. To this end, we will now sketch three ways in which a moral cosmopolitan can accept, or even endorse, the self-determination of states.

First, a cosmopolitan may hold that “to respect one another's status as ultimate units of moral concern” actually requires a certain level of state autonomy. ${ }^{63}$ How so? Consider a 
purely justice-based cosmopolitan theory, that is, one that proposes one theory of global justice to apply to all human beings across the globe. Such a position runs into the objection of pluralism concerning conceptions of justice. Given pluralism, so the objection against this position runs, imposing one conception of justice on everyone in fact fails to respect as ultimate units of moral concern those who do not share it. This objection can be defused by introducing a democracy-based component into cosmopolitanism. This component requires that people have a say in the decisions that affect their interests. Note that this does not provide us with a justification for the self-determination of states as such, but for a multi-level governance structure that states plausibly form a part of. Under this structure, political issues are dealt with at the governance level that best corresponds to the scope of the policy in question — for example, environmental issues will be dealt with at a higher level of governance than questions of educational policy. The upshot of this position is what Simon Caney calls a mixed cosmopolitan view that is sensitive both to a minimal - that is, pluralismdefying —notion of global justice and to the importance of political participation. A position of this type accepts a certain level of state self-determination on normative grounds. While some constraints based on considerations of global justice may apply to the level of selfdetermination in question, there is no incompatibility with the membership principle and fiscal policy constraint as such.

Second, a cosmopolitan may defend state self-determination as the most effective means to promote the interests of individuals worldwide. In particular, he may believe it to offer a more effective way of serving these interests than concentrating collective decision-making at the highest level, that is, in the hands of a world government. As Robert Goodin puts it, the special duties that states have towards their citizens are the best way of discharging "the general duties that everyone has towards everyone else worldwide." ${ }^{64}$ Besides, granting autonomy to states offers protection from domination as well as immunity from the larger 
unit. This allows states to be more responsive to local interests and to reduce the burdens of decision-making. ${ }^{65}$ A position of this type accepts a certain level of state self-determination on instrumental and conditional grounds. If it turns out that there is an institutional alternative that serves the interests of individuals worldwide in a better way, the justification of selfdetermination will be undermined. The same qualification would apply to an endorsement of the membership principle and the fiscal policy constraint on these grounds.

Finally, for those cosmopolitans who remain unconvinced by the two previous arguments, there is another, pragmatic reason to grant states some autonomy nonetheless. A theory of justice with practical ambitions is well-advised to take some features of the world as given, rather than attempting to reform everything at once. Arguably, the division of world politics into states is a good candidate for such a feature, given that a world without states has to be viewed as utopian from today’s perspective.

Note that adopting a pragmatic stance of this kind does not imply accepting the current state system as just. One might argue that those states benefiting from the international structure in unjust ways incur a series of redistributive obligations towards those who get short-changed under the status quo. We agree that such redistributive duties exist today. However, this article relegates them to the background. Our focus here has been to design fair rules of the game to govern fiscal interdependence between states. It is to a series of comments on the normative status of these rules that we turn in the next subsection.

In sum, a cosmopolitan theorist has at least three potential reasons to accept the kind of state self-determination implicit in our principles. Given that our position promotes the effective sovereignty of states, statists among the global justice theorists should equally find it an attractive view to hold. It seems fair to conclude that accepting our two principles does not impose an undue constraint on the theory of global justice one may want to defend. 


\section{B. An Account of Background Justice in International Taxation}

The literature on global justice has been dominated by questions concerning the relation between principles of domestic justice versus principles of global justice. While cosmopolitan theorists generally defend continuity between the two, their critics hold that the global sphere is significantly distinct from the domestic level. ${ }^{66}$ One of these alleged differences will occupy us here, namely the question of whether a global basic structure exists that gives rise to concerns of global distributive justice. ${ }^{67}$

On the one hand, a number of so-called "practice-dependent” views argue, first, that the content of our conceptions of justice is dependent on the practices they regulate and, second, that no clear structures and rules of the required kind exist at the global level to give rise to concerns of distributive justice. ${ }^{68}$ On the other hand, this position has recently been contested in two ways. First, Andreas Follesdal has argued that several of the practices of international relations are in fact constitutive of a global basic structure and, hence, that issues of global justice do indeed arise. ${ }^{69}$ Second, and more importantly in our context, Miriam Ronzoni has suggested that "the most pressing issue is not whether we have a global basic structure, but whether we need one.” ${ }^{70}$ Ronzoni makes the case that the absence of a global basic structure in the face of inequalities should not lead us to conclude that these inequalities somehow fall outside the purview of justice, but instead calls for the creation of such a basic structure. Internationally as well as domestically, certain rules may be required to guarantee the fairness of interactions between individuals. Ronzoni submits that "under circumstances of intense international interaction and interdependence the conditions of effective sovereignty, and hence of international background justice, may be eroded."71 Consequently, she advocates the creation of functionally differentiated supranational institutions that have the (legitimate) authority to set certain rules for appropriate conduct. 
This is precisely the kind of claim we have attempted to substantiate with respect to international tax competition in Section I. The current institutional setting undermines effective sovereignty. The two principles put forward in Section II are designed to restore this sovereignty and to guarantee international background justice. In fact, Ronzoni explicitly cites tax competition as one policy area where she considers international background justice to be violated and calls for interdisciplinary research on this issue. Delivering on this research program is a principal objective of this article.

Let us add two comments on this categorization of our account as one of international background justice. First, the idea of background justice emphasizes institutional reform over redistributive obligations. It favors preventative institutional reform to remedial redistribution of income. That said, note that implementing our two principles will, as a by-product, lead to a significant reduction in global inequalities.

Second, this short section cannot claim to present a comprehensive treatment of the rich literature on global justice. Our limited objective here has been to elucidate the nature of our contribution to the literature. The membership principle and fiscal policy constraint represent principles of global background justice.

\section{$\underline{\text { V. Conclusion }}$}

This article was motivated by the intuition that some effects of tax competition on fiscal selfdetermination can be qualified as unjust. The two principles defended above serve as a normative toolkit to specify to what extent the interdependence of states in fiscal matters calls for normative interdependence. The membership principle rules out any poaching of foreign capital, that is, the practice of attracting capital of non-members of a state. The fiscal policy constraint prohibits certain instances of luring, that is, the practice of inviting foreign 
individuals and corporations to follow their capital. Luring is problematic if it is both motivated by strategic intent and leads to a negative outcome collectively in terms of the aggregate extent of fiscal self-determination. To put these principles into practice, we propose the creation of an International Tax Organization (ITO), whose job description would include the settling of disputes between states about compliance issues.

To be sure, a world in which the two principles are respected is not yet a just world. It is merely a world that guarantees international background justice in one important way: national polities would regain the capacity to make collective fiscal choices about the size of the budget and the level of domestic redistribution. In other words, the principles ensure that the costs of fiscal choices fall on those who make them, at least to the extent that this can be achieved under conditions of fiscal interdependence. However, the two principles will have to be complemented by substantive principles of global tax justice. While these necessarily build on the work done in this article, they also ask the question of whether states have normative obligations to make transfer payments to other states and, if so, what they are. We hope to address this issue in future work. 


\section{Notes}

* Versions of this article have been presented at the Canadian Political Science Association (Montréal, 2010), the ECPR General Conference (Reykjavik, 2011), the Social Science Research Center Berlin (WZB) as well as at the Centre de Recherche en Éthique de l’Université de Montréal (CREUM). For comments on previous drafts of this article we thank participants at these events and, in particular, Kim Brooks, Ryoa Chung, Matthias Ecker-Ehrhardt, Tim Gemkow, Anja Görnitz, Monika Heupel, Dominic Martin, Mihaela Mihai, Jean-Pierre Vidal, Lora Viola, Daniel Weinstock, David Wiens, Jurgen de Wispelaere, and Michael Zürn. Special thanks are due to Barbara Buckinx, Miriam Ronzoni, and Christian Schemmel for detailed written comments and to Georg Simmerl for his research assistance. We acknowledge financial support from the Humboldt Foundation, the German Academic Exchange Service (DAAD), and the Social Sciences and Humanities Research Council of Canada (SSHRC).

${ }^{1}$ Notable exceptions are Gillian Brock, “Taxation and global justice: closing the gap between theory and practice,” Journal of Social Philosophy, 39 (2008), 161-84; Alexander W. Cappelen, “The moral rationale for international fiscal law," Ethics \& International Affairs, 15 (2001), 97-110 and Miriam Ronzoni, “The global order: a case of background injustice? A practice-dependent account,” Philosophy \& Public Affairs, 37 (2009), 22956. Brock discusses challenges of international taxation similar to the ones at the heart of this article, yet her account of potential solutions differs from ours in that she focuses on various kinds of global taxation rather than principles to make national taxation more effective. Cappelen analyses the current distribution of international rights to tax through 
the lens of theories of distributive justice. Ronzoni, whose work we shall discuss in more detail later, identifies tax competition as an instance of background injustice.

More common are contributions from lawyers and economists discussing normative principles of international taxation. See e.g. Richard A. Musgrave and Peggy B. Musgrave, “Inter-nation equity,” Modern Fiscal Issues, ed. R.M. Bird and J.G. Head (Toronto: University of Toronto Press, 1972), pp. 63-85; Reuven S. Avi-Yonah, International Tax as International Law (New York: Cambridge University Press, 2006).

${ }^{2}$ See Ronzoni, “The global order.” The idea of background justice is discussed in detail in Section IV.

${ }^{3}$ As is generally the case with competition, the pressure it exerts is not external to competitors' individual acts, but is in fact constituted by them. Nevertheless, competition presents a structural constraint on each individual actor, as it could only be eliminated or mitigated collectively. In that sense policy reactions by individual states are 'forced upon' them by competition.

4 The category of public goods is broadly construed here. It includes not only public infrastructure but also less tangible goods like the maintenance of a legal order or the redistribution of income and wealth.

${ }^{5}$ Reuven S. Avi-Yonah, "Globalization, tax competition, and the fiscal crisis of the welfare state,” Harvard Law Review, 113 (2000), 1573-676; James M. Buchanan and Richard A. Musgrave, Public Finance and Public Choice (Cambridge: MIT Press, 1999), pp. 29-103.

${ }^{6}$ We discuss the normative foundations of the (fiscal) self-determination of states in Section IV. 
${ }^{7}$ For a discussion of the problems associated with this assumption see Alexander Cappelen, “Responsibility and international distributive justice,” Real World Justice, ed. A. Follesdal and T. Pogge (Dordrecht: Springer, 2005), pp. 215-28 at pp. 220-22.

${ }^{8}$ John D. Wilson and David E. Wildasin, “Capital tax competition: bane or boon,” Journal of Public Economics, 88 (2004), 1065-91 at pp. 1065-6.

${ }^{9}$ States may, in theory, also compete to attract mobile individuals via taxes on labor income. Empirically, while there is some competition for individuals in very high income brackets, labor tax competition is insignificant. Cf. Peter Schwarz, "Does capital mobility reduce the corporate-labor tax ratio?” Public Choice, 130 (2007), 363-80. We bracket labor tax competition in this article.

10 Jeffrey Owens, "Written testimony of Jeffrey Owens, Director, OECD Center for Tax Policy and Administration before Senate Finance Committee on Offshore Tax Evasion, 3 May 2007” <http://finance.senate.gov/imo/media/doc/050307testjo1.pdf >; Tax Justice Network (TJN), “Tax us if you can: the true story of a global failure,” Tax Justice Network Briefing Paper (London: Tax Justice Network International Secretariat, 2005).

11 Former British chancellor Denis Healey famously said that the difference between avoidance and evasion is the "thickness of a prison wall." For a description of these and other techniques of shifting paper profits, see e.g. Brian J. Arnold and Michael J. McIntyre, International Tax Primer (Den Haag: Kluwer Law International, 1995), pp. 817. The fact that $60 \%$ of world trade is intra-firm indicates that the tax base at stake is significant.

12 Ruud A. de Mooij and Sjef Ederveen, “Corporate tax elasticities: a reader's guide to empirical findings,” Oxford Review of Economic Policy, 24 (2008), 680-697; Michael P. Devereux, "The impact of taxation on the location of capital, firms and profit: a survey of 
empirical evidence (with Data Appendix by Giorgia Maffini),” Working Paper (Warwick: University of Warwick, 2006). The fact that profit shifting is possible may explain the weaker effect of tax policies on FDI. As long as MNEs can realize tax savings without business relocations, the competition for FDI and paper profits is in a substitutive relationship. We return to this issue in Section II.

${ }^{13}$ De Mooij and Ederveen, “Corporate tax elasticities.”

${ }^{14}$ See e.g. Wilson and Wildasin, “Capital tax competition,” pp. 1069-70.

15 OECD Centre for Tax Policy and Administration, "OECD tax data base" <www.oecd.org/ctp/taxdatabase>; Steffen Ganghof, The Politics of Income Taxation (Colchester: ECPR Press, 2006), p. 1.

16 See e.g. Andreas Haufler and Guttorm Schjelderup, “Corporate tax systems and cross country profit shifting,” Oxford Economic Papers, 52 (2000), 306-25.

17 Simon Loretz, "Corporate taxation in the OECD in a wider context," Oxford Review of Economic Policy, 24 (2008), 639-660; Steffen Ganghof and Philipp Genschel, “Taxation and democracy in the EU,” Journal of European Public Policy, 15 (2008), 58-77.

${ }^{18}$ Michael Keen and Alejandro Simone, "Is tax competition harming developing countries more than developed?” Tax Notes International, 34 (2004), 1317-25.

${ }^{19}$ Christian Aid, "Death and taxes: The true toll of tax dodging” (London: Christian Aid, 2008).

20 Some observers argue that the policy choices described above-tax cuts cum base broadening, increasing reliance on indirect taxes, and low tax burdens on capital—are not caused by tax competition. They argue that these policies reflect a general shift towards market-conforming taxation that governments have implemented irrespective of competitive pressures. Cf. e.g. Sven Steinmo, “The evolution of policy ideas: tax policy in 
the 20th century,” British Journal of Politics and International Relations, 5 (2003), 20636. While it is true that there are also domestic efficiency reasons for implementing these policies, our foregoing sketch of the mechanisms shows - in line with most of the public finance literature - that these changes are to a significant extent driven by the pressures of tax competition. For more on this debate, see Thomas Rixen, “Taxation and cooperation: international action against harmful tax competition," Globalization. State of the Art and Perspectives, ed. S.A. Schirm (London: Routledge, 2007), pp. 61-80. However, as we will discuss in Section II, if such policies were indeed chosen for domestic reasons only, they would not indicate a violation of self-determination but an instance of it.

${ }^{21}$ We put "charge" in inverted commas here, because we do not mean to imply adherence to the benefit principle. See also discussion below.

${ }^{22}$ While, as we will briefly discuss below, this definition of membership is not detailed enough to resolve all cases of ambiguous membership assignments, it does nonetheless exclude certain conceptual possibilities. It should be emphasized, for example, that our definition of membership is distinct from citizenship. Permanently non-resident citizens should not be liable to tax in their country of citizenship. Conversely, temporary resident aliens, even though they generally do not have a democratic voice in state decisions, should be. We bracket these debates here.

${ }^{23}$ Mancur Olson, “The principle of 'fiscal equivalence': the division of responsibilities among different levels of government,” American Economic Review, 59 (1969), 479-87.

${ }^{24}$ See e.g. Joel Slemrod and Jon Bakija, Taxing Ourselves (Cambridge: MIT Press, 2004), pp. $61-6$.

${ }^{25}$ Thielemann, Ulrich, "Grundsätze fairen Steuerwettbewerbs - Ein wirtschaftsethisches Plädoyer für einen Steuerleistungswettbewerb,“ Regulierung oder Deregulierung der Fi- 
nanzmärkte, ed. B. Britzelmaier, S. Geberl, H.-R. Kaufmann and M. Menichetti (Heidelberg: Physica-Verlag, 2002).

${ }^{26}$ It has been proposed to replace the corporate income tax with user fees, which are unrelated to the profit made by the enterprise. The idea behind this is that redistributive taxation should only occur among individuals, and the distributed profit of companies would be taxable on the individual level as dividend income. Under our notion of fiscal selfdetermination governments would be free to choose such a system. But they may also be of the opinion that corporations can be viewed as (legal) persons that should be incorporated in a redistributive scheme. See e.g. Reuven S. Avi-Yonah, "Corporations, society, and the state: a defense of the corporate tax,” Virginia Law Review, 90 (2004), $1193-1254$.

27 See e.g. Peggy B. Musgrave, "Fiscal coordination and competition in an international setting,” Retrospectives on Public Finance, ed. L. Eden (Durham: Duke University Press, 1991), pp. 276-305; Cappelen, “The moral rationale.”

${ }^{28}$ See e.g. Musgrave and Musgrave, "Inter-nation equity”; Thomas Rixen, The Political Economy of International Tax Governance (Basingstoke: Palgrave Macmillan, 2008), pp. 57-116.

${ }^{29}$ For a discussion of the gaps and overlaps in the international tax regime with references to the vast legal and economic literature on the topic, see Rixen, The Political Economy of International Tax Governance, pp. 66-85.

${ }^{30}$ Charles M. Tiebout, “A pure theory of local expenditures,” Journal of Political Economy, 64 (1956), 416-24.

${ }^{31}$ See e.g. Dennis C. Mueller, "Redistribution and allocative efficiency in a mobile world economy,” Jahrbuch für Neue Politische Öknonomie, 17 (1998), 172-90. 
${ }^{32}$ Hans-Werner Sinn, “The selection principle and market failure in systems competition,” Journal of Public Economics, 66 (1997), 247-74. While Sinn and other contributors to the economic literature on tax competition frame this result in terms of welfare losses, we focus on the negative impact on fiscal self-determination (see Section I). Potential tradeoffs between these two perspectives are set aside in this article.

${ }^{33}$ Michael Keen, “Preferential regimes can make tax competition less harmful,” National Tax Journal, 54 (2001), 757-62; Dhammika Dharmapala, “What problems and opportunities are created by tax havens?” Oxford Review of Economic Policy, 24 (2008), 661-79 at pp. $671-6$.

${ }^{34}$ OECD, Harmful Tax Competition (Paris: OECD, 1998), p. 16.

${ }^{35}$ See “A survey of Ireland,” The Economist, 16 October 2004.

${ }^{36}$ As the literature on economic geography points out, these agglomeration economies also open up room for taxing capital without automatically leading to capital flight. See for instance Richard E. Baldwin and Paul Krugman, "Agglomeration, integration and tax harmonisation,” European Economic Review, 48 (2004), 1-23.

${ }^{37}$ That said, it remains of course an empirical question whether a race to the top actually materializes.

${ }^{38}$ See also Peter Dietsch, "Rethinking sovereignty in international fiscal policy," Review of International Studies, 37 (2011), 2107-20.

${ }^{39}$ The counterfactual nature of the criterion is in part inspired by Calvin Normore, "Consent and the principle of fairness,” Essays on Philosophy, Politics \& Economic, ed. C. Favor, G. Gaus and J. Lamont (Stanford: Stanford University Press, 2010), pp. 225-45.

40 An anonymous referee pointed out another interesting case that falls into this category. Suppose a country stratifies its tax structure in a way that frees up "armies of lawyers and 
accountants" to work "in more productive ways," thereby creating a more attractive business environment and attracting FDI. Provided this policy is formulated independently, our constraint deems it legitimate even if it leads to a reduction in the aggregate level of self-determination.

${ }^{41}$ As Christian Schemmel pointed out to us, whether the developing country should be allowed to engage in tax competition if the transfers from richer countries are not forthcoming is a different, and interesting, issue.

${ }^{42}$ See Jason C. Sharman, Havens in a Storm: The Struggle for Global Tax Regulation (Ithaca, NY: Cornell University Press, 2006).

${ }^{43}$ Calls for an International Tax Organization can be found in the literature, see e.g. Vito Tanzi, "Is there a need for a World Tax Organization? The Economics of Globalization, ed. A. Razin and E. Sadka (Cambridge: Cambridge University Press, 1999), pp. 173-186; Frances M. Horner, "Do we need an International Tax Organization," Tax Notes International, 24 (2001), 179-87. However, so far no attempt has been made to derive the institutional design from the functional requirements of the issue to be dealt with.

44 The decision-making procedures of the World Bank and the International Monetary Fund, which are heavily biased in favor of developed countries, provide a cautionary tale in this context.

${ }^{45}$ According to the ALS, foreign branches or subsidiaries of an MNE are to be taxed as if they were independent market participants, exchanging goods and services at arm’s length (i.e. market) prices, see e.g. Lorraine Eden, Taxing Multinationals (Toronto: University of Toronto Press, 1998), pp. 32-52. 
${ }^{46}$ There is an extensive literature in law and public finance on UT+FA and how it compares to separate entity accounting. For an overview, see e.g. Michael J. Graetz, Foundations of International Income Taxation (New York: Foundation Press, 2003), pp. 400-35.

47 See Convention on the Prevention and Punishment of the Crime of Genocide, art. 2 (December 9, 1948, UN General Assembly Resolution 260).

${ }^{48}$ Bernhard Zangl, “Judicialization matters! A comparison of dispute settlement under GATT and the WTO,” International Studies Quarterly, 52 (2008), 825-54 at pp. 840-1.

${ }^{49}$ For a description of the WTO dispute settlement process, see e.g. ibid.

${ }^{50}$ We thank an anonymous referee for pushing us to address this issue.

${ }^{51}$ See e.g. OECD, Harmful Tax Competition; OECD, “The Global Forum on Transparency and Exchange of Information for Tax Purposes,” Information Brief (Paris: OECD, 2011).

${ }^{52}$ For more on automatic and multilateral exchange of tax information, see David Spencer, “Tax information exchange and bank secrecy,” Journal of International Taxation, 16 (2005), 22-30; Ronen Palan, Richard Murphy and Christian Chavagneux, Tax Havens (Ithaca, NY: Cornell University Press, 2010), pp. 244-5.

${ }^{53}$ For a fuller consideration of these issues and a more detailed account of the OECD project, see e.g. Rixen, The Political Economy of International Tax Governance, pp. 130-42; Sharman, Havens in a Storm; Rixen, "From double tax."

${ }^{54}$ Philipp Genschel, Achim Kemmerling and Eric Seils, “Accelerating downhill: how the EU shapes corporate tax competition in the single market," Journal of Common Market Studies, 49 (2011), 1-22 at pp. 12-3.

${ }^{55}$ European Commission, "Council directive on a common consolidated corporate tax base (СССТВ),” COM(2011) 121/4. 
56 Thomas Rixen and Peter Schwarz, “How effective is the European Union’s savings tax Directive? Evidence from four EU member states,” Journal of Common Market Studies, 50 (2012), 151-68.

${ }^{57}$ As an anonymous referee rightly emphasized, the general analysis of feasibility should also be sensitive to issues of trajectory, that is, questions regarding the (dis)incentives different countries have to accept or promote a multilateral regulatory framework of international taxation. We bracket this issue here.

${ }^{58}$ Bruno S. Frey and Reiner Eichenberger, “To harmonize or to compete? That's not the question,” Journal of Public Economics, 60 (1996), 335-49.

${ }^{59}$ Note that these fiscal externalities suffice to impose some of the discipline in government spending that some theorists see as one of the important advantages of tax competition. See for instance Geoffrey Brennan and James M. Buchanan, The Power to Tax (Cambridge: Cambridge University Press 1980).

${ }^{60}$ Thomas W. Pogge, “Cosmopolitanism and sovereignty,” Ethics, 103 (1992), 48-75 at p. 49. ${ }^{61}$ Ibid.

${ }^{62}$ They include: Charles Beitz, Political Theory and International Relations (Princeton, NJ: Princeton University Press, 1999); Simon Caney, Justice Beyond Borders: A Global Political Theory (Oxford: Oxford University Press, 2006); Thomas Pogge, World Poverty and Human Rights (Cambridge: Polity Press, 2008).

63 Simon Caney, "Cosmopolitan justice and institutional design: an egalitarian liberal conception of lobal governance,” Social Theory and Practice, 32 (2006), 725-56 defends an argument of this sort.

${ }^{64}$ Robert E. Goodin, “What is so special about our fellow countrymen?” Ethics, 98 (1988), 663-86 at p. 681. 
65 These are some of the classic reasons given for a federal structure. See e.g. Andreas Follesdal, "Federal inequality among equals: a contractualist defense,” Global Justice, ed. T. Pogge (Oxford: Blackwell, 2001), pp. 242-61 at pp. 251-53; Wallace E. Oates, “An essay on fiscal federalism,” Journal of Economic Literature, 37 (1999), 1120-49. In addition, the existence of several smaller units allows for different experiments of life.

${ }^{66}$ See for instance the following two review articles: Simon Caney, "International distributive justice,” Political Studies, 49 (2001), 974-97 and Philippe van Parijs, “International distributive justice,” A Companion to Contemporary Political Philosophy, ed. R.E. Goodin, P. Pettit, and T. Pogge (Oxford: Blackwell, 2007), pp. 638-52.

67 John Rawls defines the basic structure of society as "the way in which the major social institutions distribute fundamental rights and duties and determine the division of advantages from social cooperation”; A Theory of Justice (Oxford, Oxford University Press, 1999), p. 6. Here, we are interested in the global basic structure.

68 See for example, Andrea Sangiovanni, "Global justice, reciprocity, and the state," Philosophy \& Public Affairs, 35 (2007), 1-39; Saladin Meckled-Garcia, “On the very idea of cosmopolitan justice: constructivism and international agency,” Journal of Political Philosophy, 16 (2008), 245-71. While we distance ourselves from one aspect of their position here, a lot more would have to be said to do their contributions justice.

${ }^{69}$ Cf. Andreas Follesdal, "The distributive justice of a global basic structure: A category mistake?” Politics, Philosophy \& Economics, 10 (2011), 46-65.

${ }^{70}$ Ronzoni, “The global order,” p. 243.

${ }^{71}$ Ibid, pp. 248-49. 